\title{
Dissociation Pressure of Aluminum Carbide Using a Rotating Knudsen Cell
}

\author{
E. R. Plante and C. H. Schreyer \\ Institute for Materials Research, National Bureau of Standards, Washington, D.C. \\ (February 17, 1966)
}

\begin{abstract}
An attempt was made to eliminate surface depletion effects in the vaporization of aluminum carbide $\left(\mathrm{Al}_{4} \mathrm{C}_{3}\right)$ by carrying out measurements in a Knudsen cell rotating at an angle of $45 \mathrm{deg}$ from the vertical. Results showed that the surface depletion effects encountered with this material are due to formation of layers of graphite over individual particles of aluminum carbide rather than to formation of a macroscopic layer of graphite over the sample. In order to achieve near-equilibrium pressures, vaporization experiments were carried out in which the sample was ground prior to each experiment and the amount of aluminum vaporized during each experiment minimized. Third law treatment of these data yielded $\Delta H^{\circ}(298)$ of $91.6 \mathrm{kcal} \mathrm{mol}^{-1}\left(383.3 \mathrm{~kJ} \mathrm{~mol}^{-1}\right)$ for the decomposition of ${ }^{1 / 4} \mathrm{Al}_{4} \mathrm{C}_{3}$ to form $\mathrm{Al}(\mathrm{g})$ and $3 / 4 \mathrm{C}(\mathrm{C})$, in good agreement with data based on calorimetric studies.
\end{abstract}

Key Words: Aluminum carbide, dissociation pressure, heat of decomposition, rotating Knudsen cell, surface depletion.

\section{Introduction}

The Knudsen method is widely used in obtaining vapor pressure data and heats and entropies of vaporization of inorganic materials. The equilibrium vapor pressure of a univariant system is a function of temperature ${ }^{1}$ only; however, since the Knudsen effusion method is a dynamic process, departure from equilibrium is possible.

The inorganic materials which undergo univariant vaporization can be divided into two classes, those which vaporize congruently and those which vaporize incongruently. Frequently, it is difficult to achieve equilibrium or near-equilibrium conditions with those materials which vaporize incongruently.

The pressure versus time curve for such materials at constant temperature typically shows an initial region in which the pressure decreases rapidly by a factor of 2 to 4 , followed by a region in which the pressure appears to have achieved a constant value within experimental error. Among the examples of incongruent vaporization reactions for which this type of vaporization behavior has been reported are

(a) the decomposition of $\mathrm{Mo}_{3} \mathrm{Ge}$ to $\mathrm{Mo}(\mathrm{c})$ and $\mathrm{Ge}(\mathrm{g})$ reported by Peavler and Searcy $[1],{ }^{2}$

(b) the decomposition of $\mathrm{TiC}$ to $\mathrm{Ti}(\mathrm{g})+\mathrm{C}(\mathrm{c})$ and $\mathrm{Cr}_{3} \mathrm{C}_{2}$ to $\mathrm{Cr}(\mathrm{g})+\mathrm{C}(\mathrm{c})$ reported by Fujishiro and Gokcen $[2,3]$,

'All temperatures in this paper are based on the 1948 IPTS.

${ }^{2}$ Figures in brackets indicate the literature references at the end of this paper. (c) the decomposition of $\mathrm{Mg}(\mathrm{OH})_{2}$ reported by Gregory and Kay [4]; and

(d) the decomposition of $\mathrm{Al}_{4} \mathrm{C}_{3}$, and $\mathrm{SiC}$ reported by Meschi and Searcy [5] and Davis, Anthrop, and Searcy [6].

Various explanations have been advanced to account for the pressure variation with time. Among these are that the vaporizing species has a low evaporation coefficient on the surface in question, i.e., that the rate of evaporation is much slower than the rate at which molecules collide with the surface under the equilibrium pressure, or that the formation of a nonvolatile surface layer (the solid decomposition product) impedes the rate of transfer of vapor from the evaporant to the effusion space sufficiently so that nearequilibrium pressures cannot be maintained. In the event that surface depletion effects are important, one can distinguish between two cases. In one case, a macroscopic layer of the nonvolatile decomposition product can be formed over the surface of the sample in the Knudsen cell and the transfer of material through this layer is rate determining. In the second case, the nonvolatile decomposition product can form a layer over each particle of the vaporizing material. In conformance with the previous usage of Davis, Anthrop, and Searcy [6], these two types of surface depletion will be referred to as macrolayering and microlayering effects, respectively. In the event that macrolayer effects are responsible for the decrease in pressure with time, rotation of a crucible making an angle of about $45^{\circ}$ from the vertical during the measurements should prevent formation of macrolayers and enable one to obtain near-equilibrium pressures. 


\section{Experimental Method}

Measurements were carried out in a conventional oil-pumped vacuum system. A graphite Knudsen cell was attached to a $1.27 \mathrm{~cm}$ O.D. stainless steel center shaft by three $0.16 \mathrm{~cm}$ diam tungsten legs. The center shaft was mounted on two precision stainless steel ball bearing assemblies which fitted snugly ingo the vacuum housing. A commercially available rotary feedthrough, modified for this work and using a magnetic coupling through the vacuum wall was connected to the center shaft by a pair of beveled gears and allowed the center shaft to be rotated at approximately $7 \mathrm{rpm}$. A rotatable flange connected the part of the vacuum system containing the rotation axis to the trap and diffusion pump. For experiments in which the crucible was rotated, this flange was rotated to about $45^{\circ}$ from the vertical. It was concluded from visual inspection of a rotating lidless Knudsen cell containing an aluminum carbide sample at room temperature that sufficient mixing of the sample would take place to prevent the formation of macrolayers of graphite over the aluminum carbide sample.

The vacuum system could be used with a conventional Vycor effusion apparatus utilizing collection of a known fraction of the vapor on fused silica or platinum targets. This technique allows one to obtain pressure-time data without opening the system to the atmosphere and is advantageous in the case of aluminum carbide because it is hydrolyzed by moist air. However, preliminary data indicated that rotation of the crucible failed to prevent a decrease in the volatility with time and because of the relatively poor precision obtained by this method when target weight gains were determined on a microbalance, this method was abandoned and further experiments carried out using the weight loss method. In these latter experiments, a conventional water cooled Vycor condenser connected to the vacuum system by a ground glass to stainless steel joint sealed with Apiezon W sealant completed the system.

The Knudsen cell was fabricated from a special grade of graphite obtained from Chance-Vought Corporation. The cell was $2.5 \mathrm{~cm}$ high by $1.9 \mathrm{~cm}$ O.D. with $0.32 \mathrm{~cm}$ thick sidewalls and an effusion hole and assumed blackbody hole of $0.1 \mathrm{~cm}$ diameter. The blackbody hole had a depth of $0.6 \mathrm{~cm}$. Heating was accomplished by induction at $450 \mathrm{kHz}$. Temperatures as measured with an NBS calibrated optical pyrometer sighted on the blackbody hole corrected for reflection of light by a window and mirror were accepted.

No radiation shields were used on the crucible. Temperature uniformity of the crucible could be achieved by careful positioning of the induction coil which was mounted on a rigid Plexiglas frame. The position of the work coil was reproduced relative to that of the crucible within a few $\mathrm{mm}$. Good temperature uniformity was inferred from the observation that in a typical experimental series, the crucible lid, which constituted about 40 percent of the internal surface area of the crucible, gained about $3 \mathrm{mg}$ and the crucible bottom gained $2 \mathrm{mg}$, while $106 \mathrm{mg}$ of $\mathrm{Al}$ was vaporized.

Choice of aluminum carbide as a test substance for the rotating effusion cell apparatus was made because measurements, since published, were in progress to determine reliable heat of formation [7] and heat capacity data [8] at NBS. In addition, mass spectrometric data [9] indicated that within the temperature range of interest, the vapor is almost pure $\mathrm{Al}(\mathrm{g})$ and previous effusion measurements [5] indicated that nonequilibrium effects might be due to the formation of a graphite macrolayer over the $\mathrm{Al}_{4} \mathrm{C}_{3}$ within the Knudsen cell.

The aluminum carbide sample used in this work was a portion of that previously used at NBS by King and Armstrong for combustion experiments [7] and by Furukawa et al. [8], for heat capacity measurements. The results of chemical analysis of portions of this material have previously been reported in detail $[7,8]$. These data showed major impurities to be approximately 1 percent free $\mathrm{Al}, 1$ percent free $\mathrm{C}$, 1.3 percent $\mathrm{AIN}$ and 2.0 percent $\mathrm{Al}_{2} \mathrm{O}_{3}$. It was assumed that nitrogen determined by the Kehldahl method was present as $\mathrm{AIN}$ and that aluminum not accounted for as $\mathrm{Al}, \mathrm{Al}_{4} \mathrm{C}_{3}$, or $\mathrm{AlN}$ was present as $\mathrm{Al}_{2} \mathrm{O}_{3}$. X-ray analysis carried out during the course of the present work showed that the sample as received contained minor phases of $\mathrm{C}(\mathrm{gr})$ and $\mathrm{Al}(\mathrm{c})$ besides $\mathrm{Al}_{4} \mathrm{C}_{3}$. After vaporization of about 30 percent of the aluminum in a sample the $\mathrm{Al}$ peak disappeared as expected. Failure to detect either $\mathrm{Al}_{2} \mathrm{O}_{3}$ or $\mathrm{AIN}$ in the $x$-ray patterns may indicate that oxygen and nitrogen were present in the sample in solid solution or as complicated carbonitrides [10] or oxycarbides [11]. However, the amounts of these materials present in the sample would be close to the limits of detection and it was not possible to establish the nature of the oxygen or nitrogen impurities on the basis of the x-ray data. On the basis of previous data [12], one would expect the $\mathrm{CO}$ pressure above an aluminum oxycarbide or $\mathrm{Al}_{2} \mathrm{O}_{3}-\mathrm{C}$ mixture to be sufficiently high so that oxygen would be preferentially lost from the Knudsen cell as $\mathrm{CO}$ during the vacuum vaporization measurements while any AIN or carbonitride would be concentrated in the condensed phase.

The procedure followed in obtaining pressure data consisted of slowly heating the crucible to a temperature of about $1500{ }^{\circ} \mathrm{K}$, allowing the background pressure to decrease to about $10^{-5}$ torr then rapidly increasing the power to the predetermined setting. The duration of the experiment was measured from the time the predetermined power level was reached to the time the oscillator was turned off. Hence, the initial deficiency in vaporized aluminum caused by the fact that the Knudsen cell is not at temperature at $t=0$ is approximately compensated by the excess of aluminum vaporized after the oscillator is turned off.

Weight changes were determined by weighing the crucible to the nearest $0.1 \mathrm{mg}$ before and after an experiment. During exposure to the atmosphere 
while in the Knudsen cell, the specimen gained weight initially at the rate of approximately $0.6 \mathrm{mg}$ per hour. Weight pick up during grinding was undoubtedly greater than this but no simple method of correcting for this effect could be made. Total time exposure to air during experiments where grinding was necessary was 10 to $15 \mathrm{~min}$ and shorter for other experiments. Leakage between the lid and crucible junction was judged to be negligible on the basis of visual inspection of the $V y c o r$ condenser surrounding the crucible.

\section{Data and Thermodynamic Treatment}

Vapor pressures were calculated using the equation $^{3}$ :

$$
P=\frac{m}{k a t}\left(\frac{2 \pi R T}{M}\right)^{1 / 2}
$$

where $m$ is the mass of aluminum vaporized, $t$ is the duration of the experiment, $a$ is the area of the effusion hole, $k$ is the Clausing correction, $T$ is the absolute temperature, $R$ is the gas constant, and $M$ is the atomic weight of the vaporizing species, $\mathrm{Al}(\mathrm{g})$. The area of the effusion hole calculated from its measured diameter was increased by 2 percent to correct for thermal expansion.

The Clausing factor $k$ corrects for the fact that the orifice has finite depth and was taken from the tabulation in Dushman [13]. For our crucible the length to radius ratio was 3.14 and $k=0.410$.

The heat and entropy change for the reaction

$$
1 / 4 \mathrm{Al}_{4} \mathrm{C}_{3}(\mathrm{c})=\mathrm{Al}(\mathrm{g})+3 / 4 C(\mathrm{c})
$$

were evaluated by the least squares solution of the approximate integrated form of the Clausius-Clapeyron equation

$$
\ln P(\operatorname{atm})=-\frac{\Delta H^{\circ}}{R T}+\frac{\Delta S^{\circ}}{R}
$$

where $\Delta H^{\circ}$ and $\Delta S^{\circ}$ are the heat and entropy changes for reaction (1) at the average temperature.

In addition, third law heats for reaction (1) were calculated using the equation

$\Delta H_{298}^{\circ}=T\left[\left(\frac{G_{T}^{\circ}-H_{298}^{\circ}}{T}\right)_{R}-\left(\frac{G_{T}^{\circ}-H_{298}^{\circ}}{T}\right)_{P}-R \ln P(\mathrm{~atm})\right]$

where $\left(\frac{G_{T}^{\circ}-H_{298}^{\circ}}{T}\right)$ is the free energy function and the subscripts $R$ and $P$ refer to reactants and products. Since free energy functions for $\mathrm{Al}_{4} \mathrm{C}_{3}(\mathrm{c}), \mathrm{Al}(\mathrm{g})$, and $\mathrm{C}(\mathrm{c})$ are well established, the average third law heat of

\footnotetext{
${ }^{3} \mathrm{~V}$ alues of constants used in the calculations were $R=8.3143 \mathrm{~J} \mathrm{~mol}^{-1}{ }^{\circ} \mathrm{K}^{-1}$ or $1.98717 \mathrm{cal}$ $\mathrm{mol}^{-1}{ }^{\circ} \mathrm{K}^{-1}$; atomic weight of aluminum 26.98: one standard atmosphere $=101,325 \mathrm{~N} \mathrm{~m}^{-2}$.
}

sublimation is more reliable than the second law heat provided dissociation pressures close to equilibrium have been obtained.

\section{Results}

Experimental results of two types were obtained in this study. In the first type of experiment, apparent pressures versus time or fraction of aluminum vaporized were obtained to try to determine the shape of these curves and the extent of departure from equilibrium pressures based on thermochemical data.

These experiments showed that rotation of the crucible had no detectable effect on the apparent vapor pressure which continually decreased as the fraction of aluminum vaporized from the sample increased. Figure 1 shows some typical volatility data expressed as weight loss/unit time versus fraction of $\mathrm{Al}$ vaporized from the sample. As is usual with this type of experiment, an initially rapid decrease in volatility is followed by a region in which the volatility appears to be essentially constant. This behavior is illustrated by the first six data points of the IV-62 data obtained at about $1870{ }^{\circ} \mathrm{K}$ shown in figure 1 . On raising the temperature to $1970{ }^{\circ} \mathrm{K}$, the same type of behavior is observed for the next seven points and when the temperature is again lowered to $1870{ }^{\circ} \mathrm{K}$ with about 0.49 of the available aluminum vaporized from the sample, the volatility is found to be only about $1 / 4$ of its previous "steadystate" value at this temperature. After grinding the sample, the last three points of the IV -62 data were obtained at about $1870{ }^{\circ} \mathrm{K}$. These points show the same type of behavior as those obtained at the beginning of the series except that the rate of decrease of volatility is slower than was observed initially. This is probably due to the smaller particle sizes present in the latter measurements. Although the IV-62 data are entirely consistent with the idea that the volatility of aluminum carbide decreased continually with the fraction vaporized, the series $\mathrm{V}-44$ data were taken in order to study this process at a constant temperature. This series of data clearly shows that at about $1915{ }^{\circ} \mathrm{K}$, no steady state pressure is ever achieved.

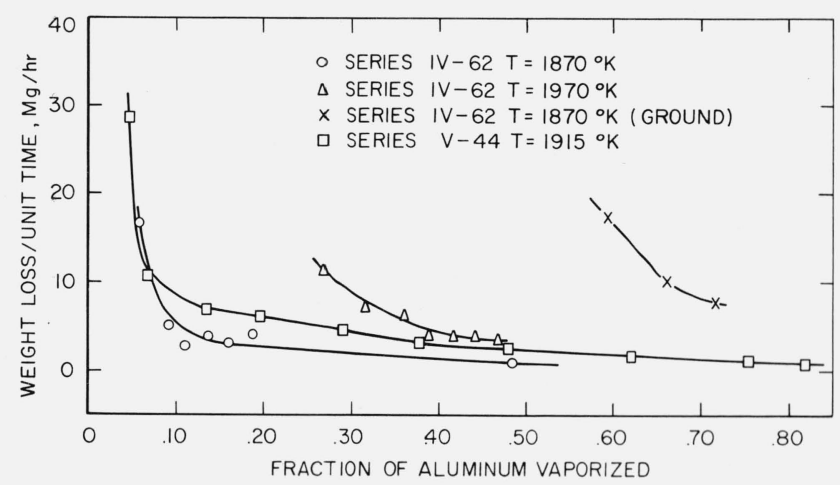

FIGURE 1. Volatility as a function of fraction of aluminum vaporized from $\mathrm{Al}_{4} \mathrm{C}_{3}$.

(a) Original sample weights were $198 \mathrm{mg}$ for series IV -62 and $134 \mathrm{mg}$ for series V-44. 
On the basis of these measurements, we conclude that in order to obtain apparent pressures anywhere near equilibrium one must take advantage of every possible factor which increases the degree of saturation within the Knudsen cell. These factors require that the sample be ground before each experiment to break up the graphite on the sample particles, and that the amount of aluminum vaporized from the sample during any experiment be kept as small as possible.

TABLE 1. Decomposition pressures and heats of decomposition of aluminum carbide ${ }^{\mathrm{a}}$

\begin{tabular}{c|c|c|c|l}
\hline Temp. & $\begin{array}{c}\text { Duration } \\
\text { of run }\end{array}$ & $\begin{array}{c}\text { Weight } \mathrm{b} \\
\text { loss }\end{array}$ & $\begin{array}{c}\text { Decomposition } \\
\text { pressure }\end{array}$ & $\Delta H^{\circ}(298)$ \\
\hline${ }^{\circ} K$ & sec & $m g$ & atm $\times 10^{4}$ & $\mathrm{kcal} / \mathrm{mol} \mathrm{Al}(\mathrm{g})$ \\
1705 & 9600 & 6.3 & 0.341 & 92.5 \\
1706 & 9600 & 3.1 & .168 & $94.9^{\mathrm{c}}$ \\
1924 & 600 & 12.6 & 11.6 & 90.6 \\
1889 & 900 & 10.2 & 6.20 & 91.3 \\
1835 & 1800 & 8.8 & 2.64 & 91.9 \\
1783 & 3600 & 8.6 & 1.27 & 92.0 \\
1810 & 2400 & 9.0 & 2.01 & 91.7 \\
1651 & 14400 & 4.9 & 0.174 & 91.8 \\
1757 & 3600 & 5.8 & .850 & 92.1 \\
1730 & 5400 & 6.8 & .659 & 91.5 \\
1863 & 14400 & 13.3 & 5.02 & 90.9 \\
1676 & 8100 & 4.1 & 0.261 & 91.8 \\
\hline
\end{tabular}

${ }^{\mathrm{a}}$ In experimental sequence.

${ }^{b}$ Orifice area at room temperature $=8.25 \times 10^{-3} \mathrm{~cm}^{-2}$, clausing factor $=0.410$, initial sample weight $=301 \mathrm{mg}$.

${ }^{c}$ This point was not included in the analysis.

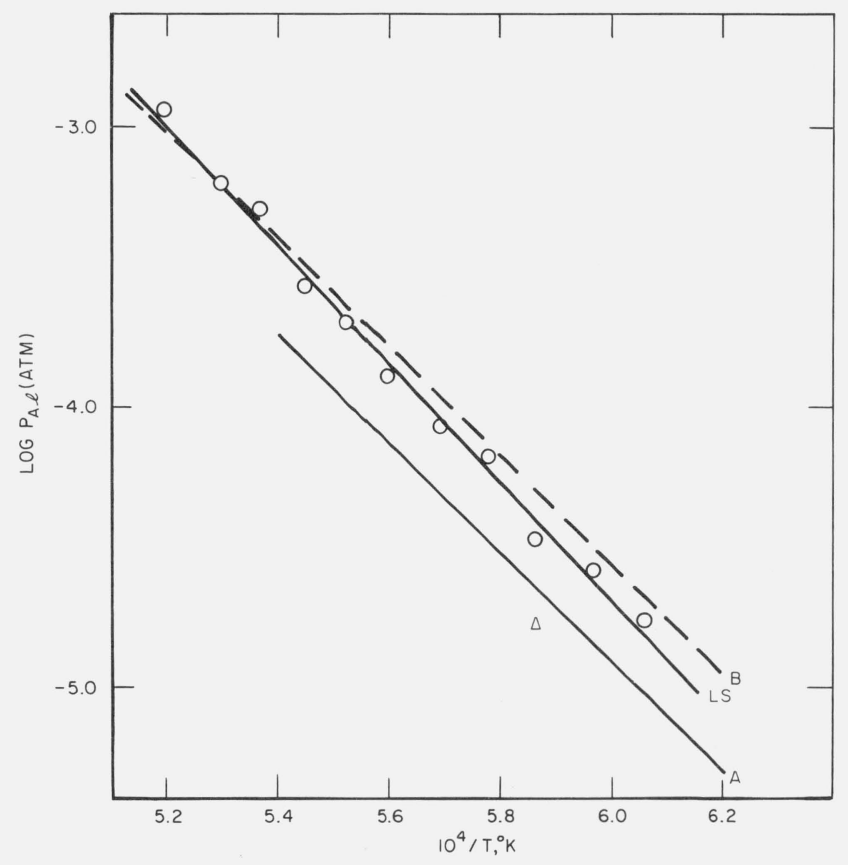

Figure 2. Clausius-Clapeyron plot of aluminum carbide dissociation pressure data.

(a) Triangular point was omitted from the least squares analysis. All points shown were obtained in this work.

(b) $L S$ is least squares line of our data.

(c) $A$ is least squares curve reported by Searcy and Meschi.

(d) $B$ is the vapor pressure curve based on the heat of formation reported by King and Armstrong [7], and thermal data reported by JANAF.
Measurements carried out in this way in an attempt to obtain equilibrium pressures are listed in table 1 and shown in figure 2. These data yield a third law heat of decomposition, using JANAF [14] free energy functions, of $\Delta H^{\circ}$ (298) for reaction (1) of $91.6 \mathrm{kcal} \mathrm{mol}^{-1}$ $\left(383.3 \mathrm{~kJ} \mathrm{~mol}{ }^{-1}\right)$ of $\mathrm{Al}$ and a standard error of 0.17 kcal mol-1 $\left(0.71 \mathrm{~kJ} \mathrm{~mol}^{-1}\right)$. Second law treatment of the same data gives a $\Delta H^{\circ}(298)$ of $99.1 \mathrm{kcal} \mathrm{mol}-1$ (414.6 kJ mol-1) and a standard error of $2.5 \mathrm{kcal}$ $\mathrm{mol}^{-1}\left(10.5 \mathrm{~kJ} \mathrm{~mol}^{-1}\right)$ of Al. These values are compared in table 2 with the values obtained from the data of Searcy and Meschi who studied the decomposition of $\mathrm{Al}_{4} \mathrm{C}_{3}$ by both the torque-Knudsen and weight loss method and with the most recent thermochemical data. Since Searcy and Meschi did not report their data in detail, the value listed in table 2 was based on their reported average pressure of $4.2 \times 10^{-6} \mathrm{~atm}$ at $1600^{\circ} \mathrm{K}$.

TABLE 2. Heat of decomposition of $1 / 4 \mathrm{Al}_{4} \mathrm{C}_{3}$

\begin{tabular}{|c|c|c|c|c|}
\hline Investigator & $\begin{array}{c}\Delta H^{\circ}(298) 3 \mathrm{~d} \mathrm{Law} \\
\mathrm{kcal} / \mathrm{mol} \mathrm{Al} \\
(\mathrm{kJ} / \mathrm{mol} \mathrm{Al})\end{array}$ & $\begin{array}{c}\text { Overall uncertainty } \\
\mathrm{kcal} / \mathrm{mol} \mathrm{Al} \\
(\mathrm{kJ} / \mathrm{mol} \mathrm{Al})\end{array}$ & $\begin{array}{c}\Delta H^{\circ}(298) 2 \mathrm{~d} \mathrm{Law} \\
\mathrm{kcal} / \mathrm{mol} \mathrm{Al} \\
(\mathrm{kJ} / \mathrm{mol} \mathrm{Al})\end{array}$ & $\begin{array}{c}\text { Standard error } \\
\mathrm{kcal} / \mathrm{mol} \mathrm{Al} \\
(\mathrm{kJ} / \mathrm{mol} \mathrm{Al})\end{array}$ \\
\hline This work & $\begin{array}{c}91.6 \\
(383.3)\end{array}$ & $\begin{array}{c}0.6 \\
(2.5)\end{array}$ & $\begin{array}{r}99.1 \\
(414.6)\end{array}$ & $\begin{array}{r}2.5 \\
(10.5)\end{array}$ \\
\hline $\begin{array}{l}\text { Meschi and } \\
\text { Searcy }\end{array}$ & $\begin{array}{c}93.7 \\
(392.0)\end{array}$ & $\begin{array}{r}3.0^{\mathrm{a}} \\
(12.6)^{\mathrm{a}}\end{array}$ & $\begin{array}{r}90.9 \\
(380.3)\end{array}$ & $\begin{array}{r}3.0^{\mathrm{a}} \\
(12.6)^{\mathrm{a}}\end{array}$ \\
\hline $\begin{array}{l}\text { King and } \\
\text { Armstrong }\end{array}$ & $\begin{array}{r}90.4^{\mathrm{b}} \\
(378.2)^{\mathrm{b}}\end{array}$ & $\begin{array}{l}1.5^{\mathrm{c}} \\
(6.3)^{\mathrm{c}}\end{array}$ & & \\
\hline Mah & $\begin{array}{r}91.4^{\mathrm{b}} \\
(382.4)^{\mathrm{b}}\end{array}$ & $\begin{array}{l}1.4^{c} \\
(5.9)^{c}\end{array}$ & & \\
\hline
\end{tabular}

${ }^{\text {a }}$ These errors, reported by the authors, appear to be overall uncertainty estimates.
b Derived from heat of formation of $\mathrm{Al}_{4} \mathrm{C}_{3}$ reported by these authors and heat of formation of $\mathrm{Al}(\mathrm{g})$ at $298{ }^{\circ} \mathrm{K}$ of $78.0 \mathrm{kcal} \mathrm{mol}^{-1}$.

${ }^{c}$ For description of the derivation of these uncertainty estimates, see text.

The overall uncertainty in the third law heat for the decomposition reaction was estimated as the sum of the squares of the uncertainties resulting from random errors $(0.51 \mathrm{kcal})$, pyrometer calibration uncertainty $(0.20 \mathrm{kcal})$, and window and prism uncertainty $(0.15$ kcal). These errors are based on three standard errors except for the pyrometer calibration uncertainty which was estimated from the uncertainties quoted on the NBS calibration certificate. It is not possible to make a reliable estimate of the error arising from nonequilibrium effects. Hopefully, part of this error will cancel because of vaporization of impurities or excess loss of vapor from the joint between the bottom and top of the crucible. The difference between the second law heat and the third law heat of about $7 \mathrm{kcal}$ may be due to a progressively greater evaporation of impurities at the higher temperatures although other sources of systematic error are also possible.

The heat for the decomposition of $\mathrm{Al}_{4} \mathrm{C}_{3}$ can also be calculated on the basis of the recent combustion studies of King and Armstrong [7] who reported $\Delta H_{f}^{\circ}(298.15)=-49.7 \pm 1.2 \mathrm{kcal}$ and Mah [15] who reported $\Delta H_{f}^{\circ}(298.15)=-53.4 \pm 2.0$ kcal. These 
values lead to the heats of decomposition shown in table 2 when combined with the heat of sublimation of $\mathrm{Al}$ of $78.0 \pm 0.4 \mathrm{kcal}$ tabulated by JANAF. However, the errors quoted by JANAF and King and Armstrong were multiplied by 3 and that reported by Mah multiplied by $3 / 2$ in order that all the uncertainties would be based on three standard deviations in the mean. These results indicate that the measured decomposition pressures of $\mathrm{Al}_{4} \mathrm{C}_{3}$ are consistent with the decomposition pressures predicted on the basis of heats of combustion and heat content data.

\section{Discussion}

One of the principal differences between our work and the results reported by Searcy and Meschi is that at no time did we observe any segregation within the crucible into macrolayers of graphite and aluminum carbide. Our results indicate that for the $\mathrm{Al}_{4} \mathrm{C}_{3}-\mathrm{C}$ system, the formation of graphite over individual particles is responsible for the decrease in volatility as the sample is vaporized. It is possible, however, that macrolayering effects might become important if the sample depth is sufficiently great.

At $1700{ }^{\circ} \mathrm{K}$, our average dissociation pressure of aluminum carbide is about 60 percent greater than the average pressure at $1700{ }^{\circ} \mathrm{K}$ reported by Meschi and Searcy. This is consistent with the observation that the volatility of $\mathrm{Al}_{4} \mathrm{C}_{3}$ decreased with the fraction of the sample vaporized (provided the sample is not disturbed by grinding) and is taken to indicate that Meschi and Searcy obtained pressure data after having vaporized a larger fraction of the sample than we had in the present study. It is also consistent with the fact that Meschi and Searcy were able to obtain pressures in torsion experiments as high as those obtained in weight loss experiments despite a less favorable ratio of orifice area to sample surface area. The approximate pressure of $\mathrm{Al}$ over $\mathrm{Al}_{4} \mathrm{C}_{3}\left(6 \times 10^{-4}\right.$ at $2100{ }^{\circ} \mathrm{K}$ ) reported by Chupka et al. [9], lower than the estimated equilibrium $\mathrm{Al}$ pressure by about a factor of ten is also consistent with these observations.

For the type of vaporization process under consideration here at least three different regions of a volatilitytime plot can be imagined. In the initial region, the surface area of the material undergoing decomposition might be sufficiently large so that equilibrium pressures are obtained, in the second region the volatility will decrease as the decomposing surface area decreases, and in the third region the rate of vaporization will be diffusion controlled.

For any particular study, the importance of these three regions will depend on the sample size, the average particle size, the sample surface area and the amount of material which has vaporized from the Knudsen cell, although for most studies the first two regions will probably be traversed so quickly that they will be of no experimental significance. Hole size correlations based on Motzfeldt's [16] or similar relations will be subject to indefinite error because of the variation in the pressure with time. In general, one can expect that the rate of decrease of volatility with fraction of sample vaporized will depend on temperature although for the limited temperature ranges used in most high temperature studies, such an effect may be of only secondary importance. One additional complicating factor is that rupture or opening of fissures in individual particles of the sample may take place because of the difference in densities of the solid product and the reactant.

In view of these many complexities, development of a method to eliminate various kinetic effects is desirable and rotation of the Knudsen cell has been our first attempt in this direction. This study has shown that microlayering is an important cause of decrease in the volatility of aluminum carbide. Work on other carbides is in progress to determine if this is a general property of carbides and if so, to attempt to develop a means of preventing formation of microlayering. Mechanically grinding the specimen within the Knudsen cell while experiments are in progress is a possibility which may hold promise if sufficient grinding can be obtained and the material problem is not too great.

\section{References}

[1] R. J. Peavler and A. W. Searcy, J. Am. Chem. Soc. 78, 2076 (1956).

[2] S. Fujishiro and N. A. Gokcen, J. Phys. Chem. 65, 161 (1961).

[3] S. Fujishiro and N. A. Gokcen, Trans. Metal. Soc. AIME 221, 275 (1961)

[4] E. Kay and N. W. Gregory, J. Phys. Chem. 62, 1079 (1958).

[5] D. J. Meschi and A. W. Searcy, J. Phys. Chem. 63, 1175 (1959).

[6] S. G. Davis, D. F. Anthrop, and A. W. Searcy, J. Chem. Phys. 34, 659 (1961).

[7] R. C. King and G. T. Armstrong, J. Res. NBS 68A (Phys. and Chem.) No. 6, 661 (1964).

[8] G. T. Furukawa, T. B. Douglas, W. G. Saba, and A. C. Victor, J. Res. NBS 69A (Phys. and Chem.) No. 5, 423 (1965).

[9] W. A. Chupka, J. Berkowitz, C. F. Giese, and M. G. Inghram, J. Phys. Chem. 62, 611 (1958).

[10] G. A. Jeffrey and V. W. Wu, Acta Cryst. 16, 559 (1963).

[11] L. M. Foster, G. Long, and M. S. Hunter, J. Am. Ceram. Soc. 39, 1 (1956).

[12] J. H. Cox and L. M. Pidgeon, Can. J. Chem. 41, 671 (1963).

[13] S. Dushman, Scientific Foundations of Vacuum Technique, $2 \mathrm{~d}$ edition, J. M. Lafferty, ed., p. 94 (John Wiley \& Sons, Inc., New York, London, 1962).

[14] JANAF Thermochemical Tables, Dow Chemical Co., Midland, Michigan (1961) Al(g) + C(c) tables dated March 31, 1961, $\mathrm{Al}_{4} \mathrm{C}_{3}$ table dated June $30,1963$.

[15] A. D. Mah, Heat of Formation of Aluminum Carbide, U.S. Bureau of Mines, Report of Investigations 6415 (1964).

[16] K. Motzfeldt, J. Phys. Chem. 59, 139 (1955).

(Paper 70A3-401) 